Forest Products Laboratory, I Forest Service

U. S. Department of Agriculture

1951

-..-

IZOBE,

BONGOSSI, ZKKKI

Lophira alata Banks

var. procera (A. '́hov.) B. Davy

Family: Ochnaceae

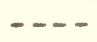

$\mathrm{BY}$

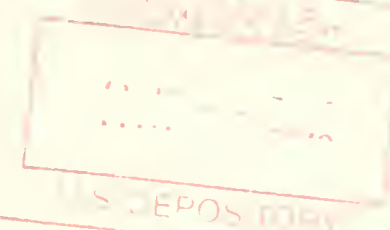

ZLISE GIRRY, Technologist

Division of Sivicultural Relations

The Lophiras occur at comparatively low elevations in the central and Atlantic coestal areas of tropical lest firica, from jenc gal to Gajon and rangine into Uganda and I'ast Sudan (5, 35, 49). . This is the onl genus of commercial importance for its timber in the family Ochnaceae. Next to Khayas, Lojhiras are the commonest trees Found, for example, in the $N_{i}$ gerian forest (i\&), and in all large forests of tropical nfrica (35).

Locally and in export trade, the wood from these trees is moin by a variety of names, mainly as azobe, bongossi, or ekki. It is also know as ironpost and red ironwood, with reference to its hardness. The trees are also known as meni-oil trees, and misleadingly, due to superificial resembiance, as African oak (2, 2 , $\underline{41}, \underline{47}$ ).

\title{
The Tree
}

\section{Size and Form}

Lorhira alata var. procera Burtt Davy is the sotanical name applied recently to the trees producing azobe wood (5, 17, 13, 24, 35). These trccs are lightloving trees (48).

Two forms of Lophiras have reviously been recognized as distinct species (5), and distinguishing characteristics of these forms, particularly as related to

Irintained at ladison, Wis., in cooperation with the University of Wiscons $+n$.

SUnderlined numbers in parenthcses refer to the iist of numbered references at the end of the article. 
the seeds, amount of parenchyna in the wood, and habits of growth, are cited and used by forest officers in Africa. To a considerable extent, however, the aifferentiations recognized appear to result from the conditions under which the trees grow (ㄴ, $2, \underline{46}, \underline{48})$.

Lophira alata Banks is generally described as the smaller form, attaining a height of 20 to 50 feet and a girth of 5 feet. It has steeply ascending branches and a narrow crown. It may be gnarled and crooked, is slow growing, and superficially resembles an oak tree. It is found in the open savannah, orchard, or dry-zone areas and is resistant to the annual grass fires (2, 10, 43. 48).

On the other hand, Lophira procera and L. alata var. procera trees (24, 36) are among the largest and most characteristic trees in the moist, evergreen rain forests. They grow on the sea coast at the inner edge of the mangrove forests (48), in freshwater swamps, and along rivers at elevations of a few hundred feet $(\overline{5}, 48)$. They may have heavy crowns and clear cylindrical boles without marked buttresses, although they may be somewhat enlarged (up to 12 feet) at the base $(2,35)$.

These trees may attain a height of 160 seet and girths of 15 to 20 feet at breast height, or up to 6 feet in diameter. They often have long boles free of branches (ㅁ) .

Strong shoots often develop from stumps. Lophiras have been favored for planting $(43)$

\section{Leaves}

The leaves, when they first appear, are brilliant rea. They may grow to a foot in length and are almost tongue-shaped (5, 48).

\section{Bark}

The bark is gray to orange-red, turning to ash-gray or black. It is thick, corky, and deeply fissurea. The "slash" is red with a yellow edge (5, 10, 48).

\section{Fruit and Flowers}

The flowers are white or yellowish and have five petals. They have a musk-like fragrance and are much more conspicuous in L. alata than in L. procera (2, 48).

The fruit is winged in both species. Onc wing is twice as long as and broader than the other in I. procera. In L. alata, one wing is nearly three times as wide as the other.

The fruit and seeds contain 30 to 40 percent of a semisolid yellow fat (Huile de Méné) that is used in trcatine leprosy (2, 2, 2, 50, 51). 


\section{Color}

The sapwood is ninkish, 2 to 4 inches wide, and distinct, whon frosh, from the licartwood, which varics in color from dull, derle rod to winc or chocolate krown with a purplish tinge. Tho heartrocd mar anpoar speckled due to licht-colored siliceous doposits in the vessels ( $2,2,16, \underline{24}, \underline{29}, \underline{35}, \underline{41}, \underline{42})$.

Grain, Toxture, and Figure

The grain is typically interlocked, and the texture is medium to rather coarse and uneren $(\underline{5}, \underline{9}, 24)$.

\section{Luster}

The luster is rated as rathor low $(5,2)$.

\section{Odor and Taste}

The wood is odorless and tasteless when dry.

\section{Weight}

Saole is heavy (2) and rill sink in water when groen, but may float when dry (14). The weight, at 12 percont moisture content, is reported as 56 to 71 pounds por cubic foot (5, 24, 4I). Spccific gravitios are recorded of 0.95 to 1.15 at 15 percent moisture content (25, 27, 34, 35) and $0.7^{i t}$ to 0.20 bascd on oven-dry weight and groen volume (5). The wood of L. Qlata tends to be less heavy than that of $\mathrm{L}$. procera (48). The wood of L. procera consists of more than 40 percent of $\overline{l i g n i n}(\underline{33})$.

\section{Mochanical Properties}

Azobc is a hard, strong wood with vory high "ircar-and-tear" rosistance (35). Mechanical tcsts have becn made in France (1, 3, 4, 6, 35, 38), Germany (26, 27, 35), and England (13, 22) and show that its mechanical properties are highor, For the most part, than comparable propertios for teak, oak, or ritch pine (35).

For equal volume, the azobc-oak static-bending ratio is reported as nearly 1.6 to 1 in favor of azobe (35).

Its strength in comprosion and static bonding is particulariy high (35); its shock rosistance is cxccllont and noarly the same as for ereenhoart. Innact resistance valucs aro also hich $(\underline{3 j})$. 
The results of a scries of tests by the Imperial Institute, Iondon (22), are given in table I. They are directly comparable, because of the methods emalo:ca. with tests by the U. S. Forest Procucts Laboratory, the Forestry Departwents in Canade and India, and the Forest Products Research Laboratory in Ingianc.

\section{Seasonins lus Shrinkage}

In Znsians (11, 12), azove is considered an extrcmely refractory species on the basis of the limited tests thus far reported. Not only does tinis timber give up its relativel: smell momout of moisture very sloily (35), but severe checking and splitting (22) ana some aistortion are likely to occur during seasoning. The neterial, worecrer, needs to e carefulij jiled (14, 41). It is thought to ie cestrable to a:m dry the naterial before it is kiln dried.

$\therefore$ miza schedule is recomended oy the English Forest Products Research Iaboratory for zizn dryng azobe (12), such as is given in taisle 2 .

Shrinizge cuming kna arying to 12 percent moisture content from the green conaition ias as fojiows (12):

$$
\begin{aligned}
& \text { Tangential - } 5.5 \text { percent } \\
& \text { Padial - } \quad 4.5 \text { percent }
\end{aligned}
$$

S-ecimens that were dried to equilinrum at 60 percent relative humidity and

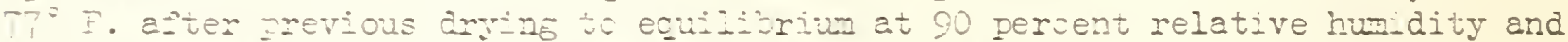
$77^{\circ}$ F. shrum 2.5 percent in the iangential direction and 2.0 percent in the radial direction.

Azobe has been rearaded as a wood that holds its shaye well when manufactured (s). Its ajsorficon cf moisture is extremely slow.

\section{2uraisitis}

Iophira procera is ratea as one of the most durabie timbers in West Africa (IC 24, 32). Locaily, it is rated as very resistant to insects, teredo (7, 34, 파), Whte ants, and decay (24, 35, 46, 48). Diles have been reported as being scuna after co years' service ( 2 ).

\section{Wortine Characteristics}

$\therefore$ abe, miti its characteristic hardness and interlocked grain, is considered ilfficult to san; even wher Ereen (22, 41), and extremely difficult to work with band tools. It can be hanaied successfully, however, with machine tools (ㅁ, 22, $\underline{2}$, 3i, 35). Azose is rated as simlar to greenheart in working characteristics and is aicout tinice as hara as Eurme teak (5;. It is also reported that it can se pianed rell; eşeciall; on the tangential surface, and with care will give a

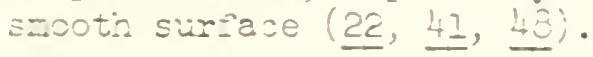


It is necessary to bore or drill azobe, preferably with power-driven tools, for nailing or bolting, but the good results obtained are thoucht to comsensate for the extra work (35). It is possible to obtain strong joints, but care is needed to prevent splitting. $\therefore$ fairly clean cut can be obtained on a turning lathe (22). Glue adheres well to this rood (22). Stains are not readıly ausorved, and a filler is needed for fonishine (22).

Uses

Although too hard for many purnoses, azobe has been found to be suitable for heavy construction, esvecially for wherves, piles, dock gates, dockng, oridefes, truck floors and jodies, railway ties, and mine slides. It is used for canoes and boats, floors, arquet material, tanks, scairstens, turnery, engraver's blociss, and handies and for novelties because of its color. It is suitale for fuel and for makine charcoal.

Although azobe has been considered rather heavy and hard for cabinet and furniture making, it has been used for billiard tailes and has been recommended for switchboards on account of ts high eleutrical resistance. Since production of azobe has recently been encouraged by the U.S. Economic Cooperation haministration, it is planned to develop utilization for furniture also, esnecially because of the wood's characteristic shape-nolding yover and resistance to wear.

Azobe is even preferred over metal and reinforced concrete for certain maritime installations and is generally rated as a construction wood of the tirst orier $(1,24, \underline{29}, 35,41,47,48)$

\section{Byproducts}

The leaves, bark, and oil-containing seeds are used medicinally in Africa for treating jaundice and leprosy (2. 2, 20, 48). The oil is also a possible source of material for soav making $(\underline{10}, \underline{48})$. The bark has been used as a remedy for malaria $(5,20)$.

\section{$\underline{\text { Sunply }}$}

Azobe is reported as being available in Ilitches, or logs of 3 to 4 feet in diameter and up to 40 feet long (24), or in squarea timbers $3 \mathrm{i}$ y 30 inches and 18 to 25 feet or more lons $(14,25)$.

Production of azobe and other tropical woous is re orted to hare been encouraged by the Lconomic Cooperation Administration through the surplying of sawn II and logbing machinery to the French in the Cameroons (20). Irior to is9, more than a million tons were exported annually from the irench colcuici.

\section{Structure}

Growth Rinfs.--Seasonal growth rıngs are absent or indistinct without masnification (5). 
Vessels.--Vessels are relatively few, rather large, and frequently blocked by deposits of yellowish-white siliceous material. They are fairly evenly distributed, scmetimes in radial groups ().

Rays.--Rays are not readily visible on cross sections without magnification (5, 2).

Parenchyma.--Parenchyma in tangential bands is abundant and has been used by some to differentiate species or varieties (2, 2, 36). 
1. Subreville, i.

1948. Les Essais üécaniques des Bois Coloniaux Africains. pp. 133-144.

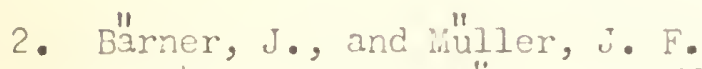

1943. Die Ifutz!.ölzer der WeIt. Vol. 3, pp. 102-105. Noudam, cermany.

3. Campredon, J.

1042. Proprietés physiques et mécaniques du bois. $18 \mathrm{pp}$. Conf. au

Centre de Perfectionement Techique.

4 .

1946. Le Pois "rat riau de Ia Construction Moderne. p. 30. Paris.

5. Chalk, L., Davy, J. B., Desch, II. E., ard Hovle, A. C.

1933. Forcst Trees and Timbers of the British Empire. Vol. II, Trenty West African Timber Trees, pp. $75-83$. Oxford, Eneland.

6. Collarciet, J.

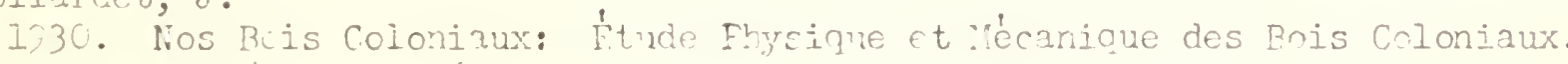
pr. 91, 95, 103, 106, 120. Paris.

7. (we) Comité Mrtional des Rois Tropicaux.

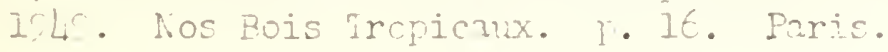

8.

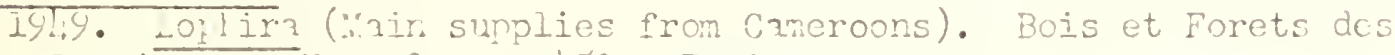
arepiques. No. 12. P. 453 . Paris.

9. Cooper, G. P. and Record, S. I.

133. Tle Everereen Forests of Liberiz. Yale School of Forestry

Bull. No. 31, pr. 30-31, illue.

20. Egreling, ... J.

1.4O. The Indifenous Trees of the Umanda Protectorate, P. 15/4-155, illus. Entebie, Uganda Protectornte, E. Africa.

11. Forest Products Research taboratory (Errlish).

1928. Wechanical and Plycicil I rorerties of Iron Fost or iendui

(Loplira procera). Forest Froducts icsearch Inboratory. Princes

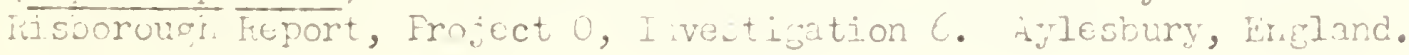

12 .

IVlf I!e ceasoning Properties of Exotic Iinkers, pt. 1. Forest Frociucts nesearch Laboratory Lenflct io. 4L, p. 4 . Xylesbry, England.

23. Foster, E. .

1914. Noies on Nirerion Trees and Pants. p. 2. Cuildford, England. 
14. H'edin, L.

1929. Sur quelques essences forestiéres exploitees au Cameroun. Rev. Bot. Appl. et d'Agr. Tropicale. Vol. 9, No. 89, pp. 39-51.

(Reviewed in Tropical Hoods Ho. 20, pp. 43-50, i929).

15. Hopkinson, A. I.

1912. Beitrge zur Hikrorraphie tropischer Holzer. Beitr. bot. Zbl. Vol. 29, No. 2, pp. 441-456.

16. Howard, A. L.

1948. A lianual of the Timbers of the Forla, 3rd ed., p. 86. London.

17. Dutcuison, J., and Dalzier, I. '..

1927. Flora of itest Tropical Africa, Vol. I. (Reviewed in Tropical Voods in. 18, p. 27.)

18.

1331. Flora of West Tropical Africa, Vol. 2.

19. Imperial Institute (Iondon)

1908. Timbers from Southem Wienexia. Imperial Institute Bull. Wo. 6, PE. 14L-155. London.

20.

1906. Seeds of Lophira alata from Sierra Leone. Imperial Inst. Bull., pp. $243-245,356-367$. indon.

21.

1;0. Some West African Timbers. Imperial Institute Bul1. No.8, pp. 231-245. London.

22 .

1926. Timbers from the Gold Coast, I. Imperial Institute Bull. No. 24, Pt. 3, pp. 417-443. London. (Reviered in iropical woods lio.9, p. 30, 1927.)

23. Irvine, F. R.

1930. Plants of the Gold Coast. Oxford, Fngland.

24. Jay, B.

1550. Timbers of West Africa, 3rd ed., pn. 32-33. Timber Development issoc., Ltd., London.

25. Jentsch, F. and Appel, F.

1936. Thizop! ora mangle, Lophira procera, Chlorophora excelsa, Musanga smittii Beschreibung trop. Holzer aus dem Jrwalde Kameruns Zeitschr. fur WeItforstwirtsckaft, Vol. 3, pF. 110-120, 235-2l.ó, 331-341,

497-506. (Ireviewed in Tropical Woods 1.0.50, p. 53, 1:37.)

26. Yollmann, $P$.

1339. Holzeigenschaftstafel Pockkolz und Bongose. Holz als Rolund Werkstoff. Tol. 2, p. 45 . 
1. Subrevilie, is.

1948. Les Éssais riécaniques des Bois Coloniaux hrricrins. np. 133-14L.

2. Bäner, J., and "üluler, $;. \bar{F}$.

1343. Die Wutzlölzer der Velt. Vol.3. pp. 102-105. Ncudamm, Gcrmany.

3. Campredor, J.

1942. Proprietés prysiques et mécaniques du bois. $18 \mathrm{pp}$. Conf. au Centre de Perftetiomement Tecinique.

4.

1946. Le Fois inat riau de Ia Construction hoderne. p. 30. Paris.

5. Chaik, L., Davy, J. B., Desch, H. E., and Hovle, A. C.

1933. Forest Trees anci Timbers of the British Empire. Vol. II, Trenty West African Timber irees, pp. is-3. Oxford, England.

6. Collarciet, J.

1530. Nos Bis Colonizux: Hende Fhycique ot "'écanique des pois Coloniaux. pp. 91, 95, 103, 1u6, 110. P2rie.

7. (uc) Comité lintional des Fois Tropicaux.

I'L. lios Bois Tropicaux. I. If. Parie.

8.

1ylg. Lotira (Wir supplies from Cameroons). Bois et Forets des eripique.s.

9. Cooper, C. I. and Iikcord, S. T.

1931. Tle Evergreun Torests of Liberia. Vale School of Forestry Buli. 31 . pr. 30-31, illixe.

10. Egrelins, - . J.

1340. The Indifenous Trees of the Uranda Protectorate, p. 154-155, illus. Enteble, Ufinda Protectorate, E. Africa.

11. Forest Iroducts Desearch Laborat or" (English.).

1928. Wecranical anci Plysical l'roperties of Iron fort or iendui

(noplirz procera). Forest Frocucts iesearch Labonatory. Princes

Iisuorousi Feport, Froject O, Invertigation $C$. dylesbury, Eragland.

12.

- Itu' IIE Senconing Propertics of Exotic Tinbers, pt. 1. Forect

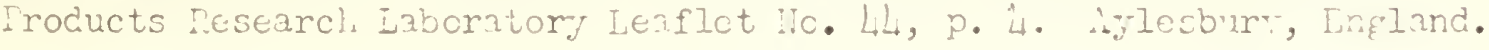

-3. Foster, E. .

1914. Notes on Niperian Trees and Plants. p. 2. Guilaford, England. 
14. Hédin, L.

1929. Sur quelques essences forestiéres exploitées au Cameroun. Rev. Bot. Appl. et d'Agr. Tropicale. Vol. 9, No. 89, pp. 39-51.

(T.eviered in Tropical Toods ITo. 20, p. 43-50, i929).

15. Hopkinson, 4. I.

1912. Beitrge zur Ilikrographie tropiscker Holzer. Beitr. Bot. Zbl. vol. 29, No. 2, pp. $44.1-456$.

16. Horard, A. L.

1948. A ranual of the Timbers of the Forld, 3rd ed., p. 86. Loncion.

17. intelisnn, J., and Dalzier, J. .

1927. Flora of Utest Tropical Africa, Vol. I. (Reviewed in Tropical Voods 10.18, p. 27.)

18.

131. Flora of West Tropical Africa, Vol. 2.

19. Imperial Institute (Iondon)

1908. Timbers from Soutlem Uiferia. Imperial Institute Bull. Ho. 6, pr. 1:44-155. Isondon.

20 .

190. Seeds of Lophira alata fron Sierra Leone. Imperial Inst. Bull., p. $243-245,366-36$ ? Tonäon.

21.

1,10. Some Test African Timbers. Imperial Inctitute Bull. No. 8. pp. 231-245. London.

22.

1926. Timbers from the Gold Coast, I. Imperial Institute Bull. No. 24, Ft. 3, pp. 417-44.3. London. (Teviered in Tropical roods 10.9 , P. 30, 1927.)

23. Irvine, F. R.

1930. Plants of the Cold Coast. Ciford, Fingland.

24. Jay, R.

1350. Timbers of West Africa, 3ra ea., pp. 32-33. Timber Development jissoc., Lt,d., Loridon.

25. Jentsch, F. and Appel,

1936. Thizop! ora mangle, Lopinira procera, Chlorophora excelsa, Musanga smithii Beschreibung trop. Holzer aus dem Nrwide Kameruns zeitschr. fur WeItforstwirtschåt, Vol. 3, pF. 110-j20, 235-21.6́, 331-341, 497-506. (reviewed in Tropical woods 1:0.50, p. 53, 1:37.)

26. Kollmann, P.

1339. Holzeigenschaftstafel Pockholz und Bongose. Holz als Rokund Werkstoff. Tol. 2, p. 45 . 
19i2. Holzeigenschaftstafel Pockholz und Bongase. Holz als Rohund Vierktoff, Vol. 5, p. 183.

28.

I750. Technologie des Holzes, Vol. I.

29. Lamb, G. N.

1950. Foreign "Toods -- Lophira. Wood Froducts, Vol. 55; No. 5, p: 23.

30. Lecompts, H.

1923. Les Bois Colontaux. Faris.

31.

1926. Une Ochnacee novelin d'Indochine. BuIl. Ms. Hist. Nut. Puris, Vol. 32, pip. 35-100.

32. Lely, I. V.

1925. The Useful Trees of Northern Yigeria. London.

33. Narmasse, Pierre

1931. Contribution a l'b́tude analytique de quelques bois coloniaux. Assn. Colonies -- Sciences and Comite Natl. des Bois Coloniaux. Faris. (Reviewed in Tropical Toods, No. 29, p. 48, 1931.)

34. Lieniaud, Jean

1930. L'action cu service forestier de la Cote d' Ivoire, II. Revue International des Products Coloniaux. Vol. 5, No. 51, pp. 113-116. Paris. (Reviewed in Tropical Woods No. 23, p. 37, 1930.)

35.

1950. L'Azobé et ses utilisations. (Translated by E. Gerry, 1951.) Bois et Forets des Tropiques ío. 15-3e mimestro, pp. 261-266, illus.

36. Ketcalfe, C. R. and Chalk, L.

1950. Anatomy of the Dicotyledons, pp. 219, 330, 338. Oxford, England.

37. Monnin, W.

1925. Comparaison entre bois coloniaux et bois metropolitains. Iravaux du Congres forestier international de Grenoble de 1925. Grenoble, France.

38.

1931. Methodes internationalos dessai et de debit des bois. lviethode francrise des essais de bois, $50 \mathrm{pp}$. Comunications au Concres Internatl. du bois et de la cylviculture, Paris.

39. Normand, D.

1334. Note sur quelquos bois du Gabon. Rev. Bot. appl. Vol. 154, pp. $414-421$. 
40. Record, S. J. and Mell, C. D.

1924. Timbers of Tropical America. p. 433. New Haven, Conn.

41. Scott, I. H.

1950. Notes on the more important African timbers imported into the Union (S. Afr.) with special reference to Portuguese East African species. Jour. S. Afr. For. Assoc. No. 19, pp. 18-62, illus.

42. Sierra Leone (W. Africa) Forest Department.

1942. Sierra Leone Native Timbers. Sierra Leone Forest Dept. Notes. Freetown, Sierra Leone, W. Africa.

43. Stebbing, E. P.

1937. Forests of West Africa and the Sahara. London and Edinburgh.

44. Stone, H.

1924. The Timbers of Commerce. London.

45. and Cox, H. A.

1922. A guide to the identification of the more useful timbers of Nigeria. London.

46. Thieme, Hans W. (Institut fur angewandte Bot., Hamburg)

1929. Das Bongosiholz und seine abstammung. Bot. Archiv., Vol. 26, Nos. 1-2, pp. 164-233, illus. Leipzig, Germany (see Chalk). (Reviewed in Tropical Toods To. 24, p. 49, 1929.)

47. Thompson, H. N.

1920. Statements by Nigerian Forest Authority for British empire Forestry Conference. London.

48. Unwin, A. H.

1920. West African Forests and Forestry, pp. 26, 356-359. London.

49. Vestal, P. A.

1937. The significance of comparative anatomy in establishing the relationship of the Hypericaceae to the Guttiferae and their allies. Prilipp. J. Sci., Vol. 64, pp. 199-256.

50. Wehmer, C.

1931. Die Pflanzenstoffe, p. 776. Jena, Germany.

51. Wiesner, J. von

1928. Die Rohstoffe des Pflanzenreichs, Vols. I-2, pp. 763, 1532-3. Leipzig, Germany. 
Table 1.--Results of mechanical tests on Lophira proceral conducted by the Imperial Institute, London (르)

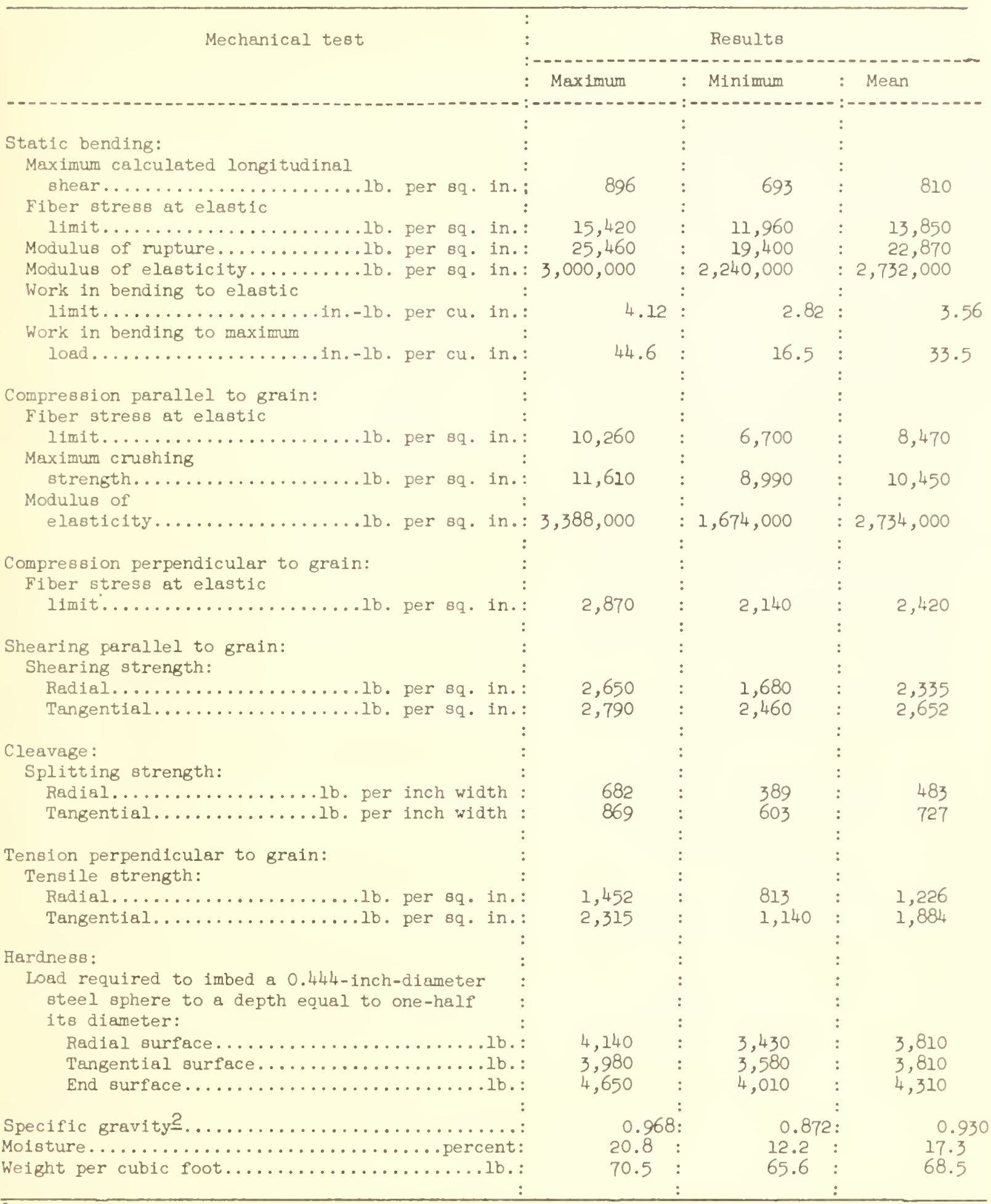

The material used was two air-dry planks, 10 feet long, 33 inches wide, and 3 inches thick. Based on weight when oven-dry and volume at test.

Report No. R1913

z $489993 \mathrm{~F}$ 

Table 2.--kiln schedule for drying azobel

Moisture content of the

wettest timber on the air-inlet : side at rich chanes are to be : made

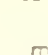

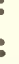

Tempernture

: Temperature

(dry bulb): (ret bulb):

$:$

$-:-$

:

Green....................

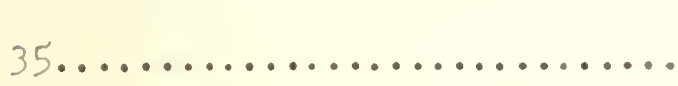

$30 \ldots \ldots \ldots \ldots \ldots \ldots \ldots \ldots$

$25 \ldots \ldots \ldots \ldots \ldots \ldots \ldots \ldots \ldots$

$22 \ldots \ldots \ldots \ldots \ldots \ldots \ldots \ldots \ldots \ldots \ldots \ldots \ldots \ldots \ldots$

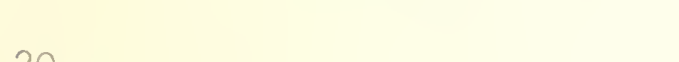

$20 \ldots \ldots \ldots \ldots \ldots \ldots \ldots \ldots$

$18 \ldots \ldots \ldots \ldots \ldots \ldots \ldots \ldots \ldots$

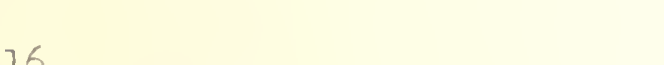

$16 \ldots \ldots \ldots \ldots \ldots \ldots \ldots \ldots . \ldots \ldots$

$14 \ldots \ldots \ldots \ldots \ldots \ldots \ldots \ldots$

\begin{tabular}{|c|c|c|c|c|c|c|c|}
\hline \multirow{3}{*}{$\frac{{ }_{\mathrm{F}}}{105}$} & $:{ }^{\circ} \mathrm{C}$. & : & ${ }^{\circ} \mathrm{F}$. & : & ${ }^{\circ} \mathrm{C}$. & : & Percent \\
\hline & : & : & & : & & : & \\
\hline & $: \angle C \cdot 5$ & : & 101 & : & 38.0 & : & 85 \\
\hline & : & : & & : & & $:$ & \\
\hline 105 & $: 4 C .5$ & : & 99 & : & 37.5 & : & 80 \\
\hline & : & : & & : & & : & \\
\hline 110 & $: 43.5$ & : & 102 & : & 39.0 & : & 75 \\
\hline & : & : & & : & & : & \\
\hline 110 & $: 4.3 .5$ & : & 100 & : & 38.0 & : & 70 \\
\hline & : & : & & : & & : & \\
\hline 115 & : LK. 0 & : & 103 & : & 39.5 & : & 65 \\
\hline & : & : & & : & & : & \\
\hline 120 & $: 4.0 .0$ & : & 105 & : & 41.0 & : & 60 \\
\hline & : & : & & : & & $:$ & \\
\hline 125 & $: 51.5$ & : & 107 & : & 42.0 & : & 55 \\
\hline & : & : & & : & & : & \\
\hline 130 & $: 51 \cdot 5$ & : & 109 & : & 43.0 & : & 50 \\
\hline & : & : & & : & & : & \\
\hline 135 & $: 57.0$ & : & 111 & : & 43.5 & : & 45 \\
\hline & : & : & & : & & : & \\
\hline
\end{tabular}

IRevised Kiln Schedule 2, Porest Products Pesearch Laboratory (English) Leaflet No. 42, 1948. Aylesbury, Engiand. 
